\title{
Baseline Gene Expression Levels in Falkland-Malvinas Island Penguins: Towards a New Monitoring Paradigm
}

\author{
Lizabeth Bowen ${ }^{1, *}$, Shannon Waters ${ }^{1}$, Jeffrey L. Stott ${ }^{2}$, Ann Duncan ${ }^{3}$, Randi Meyerson ${ }^{4}$ and Sarah Woodhouse ${ }^{5}$ \\ 1 U.S. Geological Survey, Western Ecological Research Center, One Shields Avenue, Davis, CA 95616, USA; \\ swaters@usgs.gov \\ 2 Department of Pathology, Microbiology and Immunology, University of California, One Shields Avenue, \\ Davis, CA 95616, USA; jlstott@ucdavis.edu \\ 3 Detroit Zoo, 8450 W. 10 Mile Road, Royal Oak, MI 48067, USA; aduncan@dzs.org \\ 4 Independent Researcher, Farmington, MI 48332, USA; randimeyerson61@gmail.com \\ 5 Henry Doorly Zoo and Aquarium, 3701 S 10th St, Omaha, NE 68107, USA; Sarah.Woodhouse@omahazoo.com \\ * Correspondence: lbowen@ucdavis.edu; Tel.: +1-530-574-4353
}

check for updates

Citation: Bowen, L.; Waters, S.; Stott,

J.L.; Duncan, A.; Meyerson, R.;

Woodhouse, S. Baseline Gene

Expression Levels in

Falkland-Malvinas Island Penguins:

Towards a New Monitoring

Paradigm. Life 2022, 12, 258. https://

doi.org/10.3390/life12020258

Academic Editors: Michael Sheriff

and Abbey Wilson

Received: 2 November 2021

Accepted: 21 January 2022

Published: 9 February 2022

Publisher's Note: MDPI stays neutral with regard to jurisdictional claims in published maps and institutional affiliations.

Copyright: (c) 2022 by the authors. Licensee MDPI, Basel, Switzerland. This article is an open access article distributed under the terms and conditions of the Creative Commons Attribution (CC BY) license (https:// creativecommons.org/licenses/by/ $4.0 /)$.

\begin{abstract}
Health diagnostics of wildlife have historically relied on the evaluation of select serum biomarkers and the identification of a contaminant or pathogen burden within specific tissues as an indicator of a level of insult. However, these approaches fail to measure the physiological reaction of the individual to stressors, thus limiting the scope of interpretation. Gene-based health diagnostics provide an opportunity for an alternate, whole-system, or holistic assessment of health, not only in individuals or populations but potentially in ecosystems. Seabirds are among the most threatened marine taxonomic groups in the world, with $\sim 25 \%$ of this species currently listed as threatened or considered of special concern; among seabirds, the penguins (Family Spheniscidae) are the most threatened seabird Family. We used gene expression to develop baseline physiological indices for wild penguins in the Falkland-Malvinas Islands, and captive zoo penguins. We identified the almost complete statistical separation of penguin groups (gentoo Detroit Zoo, gentoo FalklandMalvinas Islands, rockhopper Detroit Zoo, and rockhopper Falkland-Malvinas Islands) based on gene expression profiles. Implementation of long-term longitudinal studies would allow for the assessment of temporal increases or decreases of select transcripts and would facilitate interpretation of the drivers of change.
\end{abstract}

Keywords: transcriptomics; penguins; wildlife monitoring; Falkland-Malvinas Islands

\section{Introduction}

Traditional evaluation of the health status of wildlife is based on a combination of the animal's history (e.g., movement, reproductive status), physical examination, and clinical pathology data. Many studies focusing on sensitive populations are disease-centered, while relatively few studies focus on differences in host susceptibility, which may be due to differences in the host immune response [1] and can be influenced by factors such as nutrition, contaminants, and pathogens [2]. Additionally, although the exact cause of most species declines is unknown, declines are likely associated with multiple and potentially synergistic environmental stressors. Historically, large-scale investigations into populations and ecosystems have been driven by species declines and/or mortality events. However, by the time these events are observed, ample time has elapsed in systems already operating sub-optimally for additional conditions to manifest, preventing clear insight into the causal factors. Alternatively, using a proactive approach of baseline and long-term monitoring to continually assess populations for subtle yet significant changes would provide baseline data sets upon which perturbations in real time could be assessed.

Gene-based techniques have the ability to improve our understanding of the stressor/immune function/disease triad by measuring the physiological response of individuals 
to disease as well as the influence of external or environmental factors on the health of an individual and, collectively, the population. Gene expression is the process by which information from the DNA template of a particular gene is transcribed into messenger RNA (mRNA) and eventually translated into a functional protein. The earliest observable signs of health impairment are altered levels of gene transcripts that are evident prior to clinical manifestation [3]. The amount of a particular gene that is transcribed is physiologically dictated by a number of intrinsic and extrinsic factors, including stimuli such as infectious agents, contaminant exposure, nutritional deficit, or trauma [4-7]. The use of novel molecular techniques may help identify these and other factors contributing to host susceptibility, which is critical to developing strategies to mitigate the effect of stressors on wildlife populations [8].

As an example, seabirds have a global distribution, are vital components of coastal marine ecosystems, and may connect marine and terrestrial environments at a global scale [9-11]. Because seabirds are dependent on a variety of ecosystems, they are vulnerable to both marine and terrestrial environmental stressors and the synergistic effects of combined stressors [11]. Not surprisingly, seabirds are the most threatened marine taxonomic group in the world, with $\sim 25 \%$ of this species currently listed as threatened or considered of special concern [12]. Among seabirds, the penguins (Family Spheniscidae) are the most threatened seabird Family [12]. Populations of many penguin species have declined substantially in the past two decades. In 2013, 11 species (60\%) were listed as threatened (five endangered and six vulnerable), two as near-threatened, and five as of least concern [13]. The Falkland-Malvinas Islands are a marine biodiversity hotspot and important for penguin conservation because they have important breeding populations of four penguin species (king (Aptenodytes patagonicus), gentoo (Pygoscelis papua), southern rockhopper (Eudyptes chrysocome), and Magellanic (Spheniscus magellanicus)), with the largest breeding populations of southern rockhopper and gentoo penguins [14]. The abundance of penguins in the Falkland-Malvinas Islands declined by $84 \%$ during the 1980 s and 1990s. Southern rockhopper penguins are the most threatened penguin in the Falkland-Malvinas Islands (vulnerable on the IUCN Redlist; [15]) and are considered threatened under the US Endangered Species Act. Gentoos are considered near-threatened, with a decreasing population (IUCN Redlist; [15]).

The broad goal of our project was to develop the methodology for and provide a baseline assessment of select gene expression levels in penguins in the Falkland-Malvinas Islands. This baseline will be a reference from which future measurements, and thus subtle yet significant alterations in physiological status, can be made in real time, prior to catastrophic events. We compared the expression of targeted genes within and between gentoo and rockhopper penguin populations sampled in the Falkland-Malvinas Islands and between these penguins and captive penguins of both species. With these assays, we provide initial transcript-based analyses and results for penguin populations that can be used as reference to help identify individual, population, and ecosystem changes in the future [5]. These assays can be adapted globally and across species, and ultimately may provide early-warning indicators and help us better understand the susceptibility of individuals, populations, and ecosystems to risks from changing conditions. Similar gene expression profiling has been adapted for use with multiple and divergent species and has also been used successfully as a predictor of mortality [4-7].

\section{Materials and Methods}

\subsection{Falkland-Malvinas Islands}

Fieldwork was conducted during the 2019 nesting season (late November to early December). We conducted health and welfare assessments for gentoo and rockhopper penguins at two study sites: Dunbar in the west Falkland-Malvinas (hereafter, islands), which has little shipping/oil development $\left(\sim 51^{\circ} 22^{\prime} \mathrm{S}, 60^{\circ} 38^{\prime} \mathrm{W}\right)$, and Berkeley Sound in the east islands near Stanley, which has heavy shipping activity $\left(\sim S 51^{\circ} 33^{\prime}, 57^{\circ} 46^{\prime} \mathrm{W}\right.$, Figure 1). 
The two study sites are separated by distance and by the prevailing ocean currents, which flow in opposite directions at each site (Figure 1).

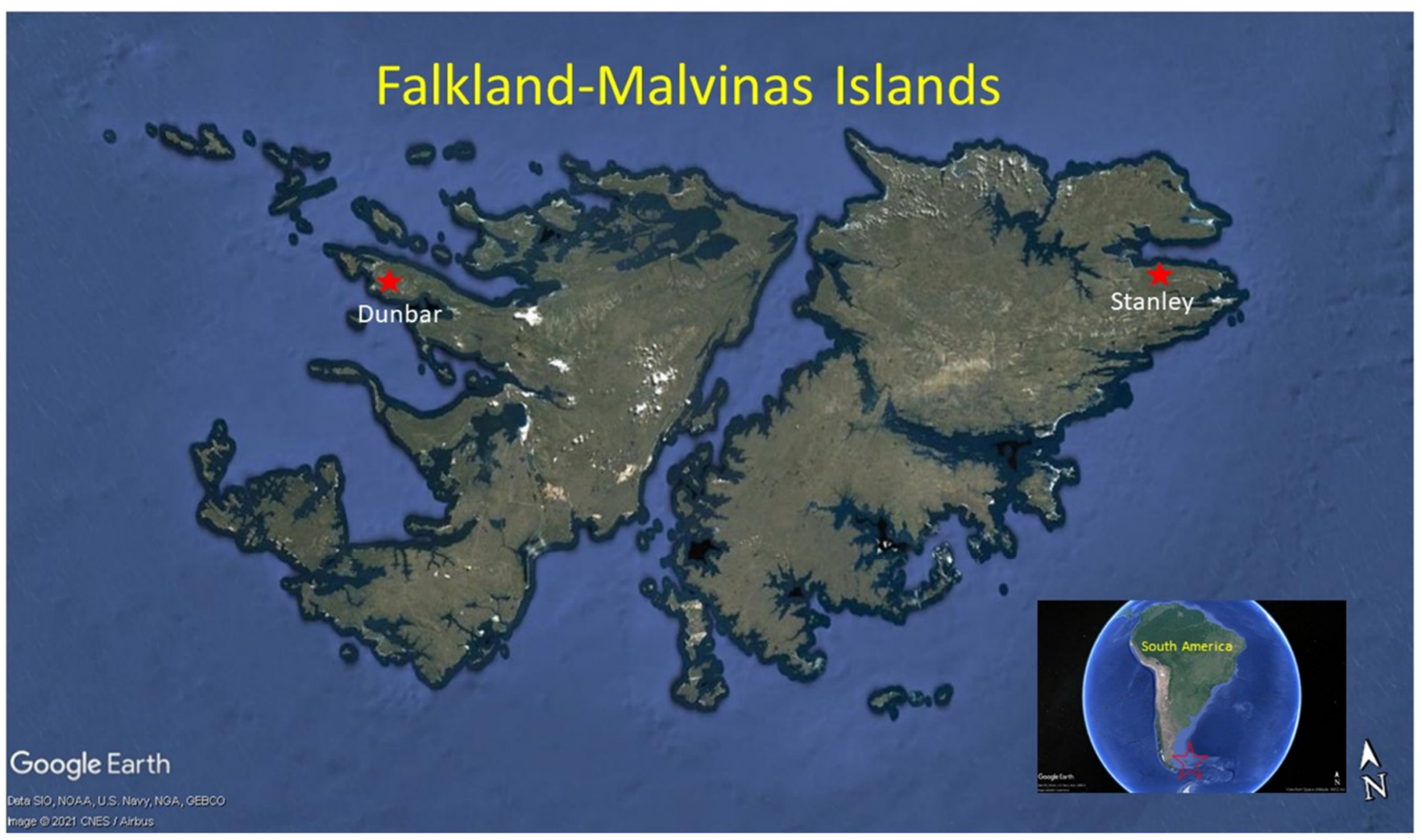

Figure 1. Gentoo and rockhopper penguin sampling sites at two colonies in the Falkland-Malvinas Islands (Dunbar and Stanley).

All handling was performed near the nesting sites, at a distance that did not elicit a response from the nesting penguins. We sampled 39 gentoo and 34 rockhopper penguins. Penguins were manually restrained by animal care staff from the Detroit Zoological Society who are experienced in handling penguins. All penguins in the study received a complete physical exam by a veterinarian. The time of manual restraint to complete the exam and sampling was 5-10 min per bird. Any abnormal findings were recorded. Samples were stored in a liquid nitrogen storage tank for 4-7 days before being transferred to a $-80{ }^{\circ} \mathrm{C}$ freezer.

\subsection{Detroit Zoo}

We sampled 23 gentoo and 15 captive rockhopper penguins located at the Detroit Zoo, Michigan. Sampling did not occur during breeding season. All penguins of each species received the same diet/water quality/husbandry and lived in the same habitat. Penguins were manually restrained by animal care staff from the Detroit Zoological Society who are experienced in handling penguins. The time of manual restraint to complete measurements and sampling was 5-10 min per bird. All penguins in the study received a complete physical exam by a veterinarian. Any abnormal findings were recorded, and all birds were considered to be healthy. Each bird had been previously banded on the wings using color-coded bands.

\subsection{Blood Collection and RNA Extraction}

Blood was collected from the jugular vein using a 20-gauge needle. A 0.5 -mL blood sample from each penguin was then placed into a blood collection tube with RNA preservative buffer (Captive: RNeasy Animal Protect, Qiagen, Valencia, CA, USA; Wild: DNA/RNA 
Shield Blood Collection Tubes, Zymo Research, Irvine, CA, USA), shipped at room temperature per manufacturer's instructions, and stored at $-20{ }^{\circ} \mathrm{C}$ prior to extraction of RNA [16]. RNA isolation methods do not influence quality or quantity of RNA [17]. We selected samples randomly for processing (i.e., samples were not processed in batches according to location, age, sex, or pathogen-exposure status).

\subsection{Captive Penguins}

Blood samples were placed directly into RNeasy Protect Animal Blood Tubes (Qiagen, Valencia, CA, USA) and then frozen at $-20{ }^{\circ} \mathrm{C}$ until extraction of RNA [16]. Rapid RNA degradation and induced expression of certain genes after blood draws have led to the development of methodologies for preserving the RNA expression profile immediately after blood is drawn. The RNeasy Protect Animal Blood Tube contains a blend of RNA stabilizing reagents that protect RNA molecules from degradation by RNases and prevent further induction of gene expression. The RNA from blood in RNeasy Protect Animal Blood Tubes was isolated according to manufacturer's standard protocols, except that each sample was initially split in half to account for the nucleated red blood cells. The extracted RNA was stored at $-80^{\circ} \mathrm{C}$ until analysis [18].

The RNA was then cleaned up using the Zymo RNA Clean and Concentrator-25 kit. The RNA from the previous procedure $(60 \mu \mathrm{L})$ was added to $40 \mu \mathrm{L}$ of molecular water to make a total of $100 \mu \mathrm{L}$, and then $200 \mu \mathrm{L}$ of RNA binding buffer was added. The manufacture's standard protocol (page 3) was followed, which included an in-column DNase treatment to remove contaminating gDNA. Extracted RNA was stored at $-80{ }^{\circ} \mathrm{C}$ until analysis. We measured RNA concentration and clarity using a Qubit 3.0 Fluorometer with the Qubit Broad Range and the RNA, DNA, and RNA IQ Assay Kits (Life Technologies, Carlsbad, CA, USA).

\subsection{Wild Penguins}

The Zymo DNA/RNA Shield blood collection tubes were inverted 10 times prior to sample removal. RNA was extracted following modified procedures of Zymo Quick-RNA Whole Blood kit recommended by Zymo Technical Support. Following the Nucleated Whole Blood procedure on page 6 starting at step 2, the $100 \mu \mathrm{L}$ sample was treated with $800 \mu \mathrm{L}$ PK Digestion Buffer and $20 \mu \mathrm{L}$ Proteinase $\mathrm{K}$ and then incubated at $55^{\circ} \mathrm{C}$ for $30 \mathrm{~min}$. Following this step, the sample was purified using the procedure on page 3 starting at step 3. The samples were treated with in-column DNase treatment to remove contaminating gDNA. Extracted RNA was stored at $-80{ }^{\circ} \mathrm{C}$ until analysis. RNA concentration and clarity were measured on a Qubit 3.0 Fluorometer using the Qubit Broad Range with the RNA, DNA and RNA IQ Assay Kits (Life Technologies, Carlsbad, CA, USA).

\section{6. cDNA Synthesis}

We performed a standard cDNA synthesis on 2 ug of RNA template from each penguin. Reaction conditions included four units reverse transcriptase (Omniscript ${ }^{\circledR}$; Qiagen, Valencia, CA, USA), $1 \mathrm{uM}$ random hexamers, $0.5 \mathrm{mM}$ each $\mathrm{dNTP}$, and 10 units RNase inhibitor, in reverse transcription buffer (Qiagen). We incubated reactions for $60 \mathrm{~min}$ at $37{ }^{\circ} \mathrm{C}$, followed by an enzyme inactivation step of $5 \mathrm{~min}$ at $93{ }^{\circ} \mathrm{C}$, and then stored samples at $-20^{\circ} \mathrm{C}$ until further analysis.

\subsection{Gene Selection}

The genes examined in our study can be grouped into functional categories that include immune modulation, pathogen response, inflammation, cell signaling, xenobioticmetabolizing enzymes, and cellular stress response, and were largely selected based upon their potential to be modified by biological, physical, or anthropogenic injury, thus providing information on the type and magnitude of stressors associated with the penguin's internal or external environment (Table 1). Specifically, genes were chosen to reflect potential influences of known stressors in the penguins' environments, both wild and captive. 
These include stressors associated with climate change (e.g., emerging infectious diseases, thermal stress, and nutritional stress), increased oil exploration (e.g., hydrocarbon exposure), and increasing tourism (e.g., general stress due to increased human presence). The functionality and response of each gene have been validated in other studies and are well-documented in the literature (Table 1).

Table 1. Genes and corresponding functions selected for gentoo- and rockhopper-specific quantitative PCR panel.

\begin{tabular}{|c|c|c|}
\hline Gene & Gene Function & General Category \\
\hline YWHAZ & Reference gene [19] & Reference \\
\hline IFIT5 & $\begin{array}{c}\text { Interferon Induced Protein With Tetratricopeptide Repeats } 5 \text { (IFIT5) is part of } \\
\text { a novel class of IFN-effectors, known as IFN-induced proteins with } \\
\text { tetratricopeptides repeats (IFITs). IFIT proteins are indicative of early } \\
\text { response to virus [20,21]. }\end{array}$ & Inflammation \\
\hline IL-6 & $\begin{array}{l}\text { Interleukin } 6 \text { (IL-6) is a cytokine that stimulates the synthesis of the full } \\
\text { spectrum of acute phase proteins as seen in inflammatory states [22]. The } \\
\text { term "acute phase response" (APR) is referred to a nonspecific and complex } \\
\text { reaction of an organism that occurs shortly after any tissue damage, such as } \\
\text { infection, trauma, neoplasia, inflammation, and stress [23]. }\end{array}$ & Inflammation \\
\hline MHC & $\begin{array}{l}\text { Major histocompatibility complex class II beta (MHC) molecules play a key } \\
\text { role in the adaptive immune responses of vertebrates. MHC class II beta has } \\
\text { primarily been associated with extracellular infections (e.g., bacteria) [24]. }\end{array}$ & Targeted immunity \\
\hline Nr3c1 & $\begin{array}{c}\text { Nuclear Receptor Subfamily } 3 \text { Group C Member } 1(\mathrm{Nr} 3 \mathrm{c} 1) \text { is a glucocorticoid } \\
\text { receptor expressed in response to stress [25]. }\end{array}$ & Stress response \\
\hline TNFRSF6 & $\begin{array}{l}\text { Tumor necrosis factor receptor super family } 6 \text { (TNFRSF6) is instrumental in a } \\
\text { number of cellular signaling pathways involving inflammation, apoptosis, } \\
\text { lymphocyte homeostasis, and tissue development [26]. TNFRSF6 also plays } \\
\text { a prominent role in apoptotic clearance of virus-infected cells [27]. }\end{array}$ & Inflammation \\
\hline AHR & $\begin{array}{l}\text { The aryl hydrocarbon receptor (AHR) responds to classes of environmental } \\
\text { toxicants including polycyclic aromatic hydrocarbons, polyhalogenated } \\
\text { hydrocarbons, dibenzofurans, and dioxin [28]. Birds have been found to } \\
\text { have different sensitivities to PHAHs and TCDD exposure in comparison to } \\
\text { other species; this can be due to expression differences in AHR [29]. }\end{array}$ & Detoxification \\
\hline THRa & $\begin{array}{l}\text { Thyroid hormone receptor alpha (THRa) is associated with physiological } \\
\text { stress and organic compound exposure [30]. }\end{array}$ & Stress response \\
\hline HSP70 & $\begin{array}{l}\text { The heat-shock protein } 70 \text { (HSP70) is produced in response to exposure to } \\
\text { different kinds of environmental stress conditions, such as infection, } \\
\text { inflammation, exercise, exposure of the cell to toxins, starvation, and thermal } \\
\text { or other stress [31,32]. In addition to being expressed in response to a wide } \\
\text { array of stressors, heat-shock proteins act as molecular chaperones [33]. In } \\
\text { incubating female eiders, an increase in HSP70 resulted in a decrease of } \\
\text { immunoglobulin [34]. }\end{array}$ & Stress response \\
\hline IL-18 & $\begin{array}{c}\text { Interleukin-18 (IL-18) plays an important role in inflammation and host } \\
\text { defense against microbes. Induction of IL-18 initiates a TH1 immune } \\
\text { response in chickens }[35,36] \text {. }\end{array}$ & Inflammation \\
\hline Gata3 & $\begin{array}{c}\text { Gata3 is a TH2-specific transcription factor that controls transcription of } \\
\text { cytokines Interleukin (IL) IL-4, }-5 \text {, and }-13 \text { [37]. Gata3 is involved in innate } \\
\text { and adaptive immune responses to parasitic helminths [38]. Gata3 has also } \\
\text { been shown to be involved in adipocyte development in Adelie penguin } \\
\text { chicks [30]. }\end{array}$ & $\begin{array}{l}\text { Innate and adaptive } \\
\text { immune function }\end{array}$ \\
\hline
\end{tabular}


Table 1. Cont.

\begin{tabular}{|c|c|c|}
\hline Gene & Gene Function & General Category \\
\hline PRDX4 & $\begin{array}{l}\text { Peroxiredoxin } 4 \text { (PRDX4) protects against oxidative damage by scavenging } \\
\text { reactive oxygen species in both the intracellular (especially the endoplasmic } \\
\text { reticulum) compartments and the extracellular space [39-41]. }\end{array}$ & Oxidative stress response \\
\hline PRDX6 & $\begin{array}{l}\text { Peroxiredoxin } 6 \text { (PRDX6) plays a role in redox regulation, phospholipid } \\
\text { turnover, and protection against oxidative injury [39-41]. }\end{array}$ & Oxidative stress response \\
\hline GHR & $\begin{array}{l}\text { Growth hormone receptor (GHR) is associated with nutrition, growth, and is } \\
\text { a regulator of aging and plays a significant role in cancer } \\
\text { development }[42,43] \text {. GHR expression is decreased in association starvation } \\
\text { in some species [44]. }\end{array}$ & Nutrition \\
\hline VEGFA & $\begin{array}{l}\text { Vascular endothelial growth factor A (VEGFA) is a cytokine involved in } \\
\text { immune suppression [45]. }\end{array}$ & Immune suppression \\
\hline
\end{tabular}

\subsection{Polymerase Chain Reaction Primers}

We designed degenerate primers from multispecies alignments (GenBank) as previously described [46]. Briefly, we utilized degenerate primer pairs developed for the penguin on cDNA from 3 randomly selected gentoo and rockhopper samples. We designed degenerate primer pairs to amplify the genes of interest and two reference genes (Table 1; [46]). We performed PCR amplifications using these primers on $1 \mu \mathrm{L}$ of each cDNA sample in $24.5 \mu \mathrm{L}$ volume containing $20 \mu \mathrm{L}$ of water, $2.5 \mu \mathrm{L} 10 \times$ Advantage 2 PCR buffer, $0.5 \mu \mathrm{L}$ $50 \times \mathrm{dNTP}$ Mix, $0.5 \mu \mathrm{L}$ of each primer, and $0.5 \mu \mathrm{L} 50 \times$ Advantage 2 polymerase mix of Advantage ${ }^{\circledR} 2$ Taq polymerase (Clontech, Palo Alto, CA, USA). We performed the PCR on an BioRad C1000 Thermal Cycler (Hercules, CA, USA); it consisted of 1 cycle at $95^{\circ} \mathrm{C}$ for $1 \mathrm{~min}$, and then 40 cycles at $95^{\circ} \mathrm{C}$ for $30 \mathrm{~s}$, at $68^{\circ} \mathrm{C}$ for $1 \mathrm{~min}$, and $68^{\circ} \mathrm{C}$ for $1 \mathrm{~min}$; the ramp-up throughout was $1{ }^{\circ} \mathrm{C} / \mathrm{s}$, followed by a hold phase for $12^{\circ} \mathrm{C}$ indefinitely. We electrophoresed the products of these reactions on $1.5 \%$ agarose gels and visualized resulting bands using BioRad U-View. We excised from the gel definitive bands representing PCR products of a predicted base-pair size of the targeted gene and extracted and purified them using a commercially available nucleic acid-binding resin (Zymoclean Gel DNA Recovery Kit). We determined nucleotide sequences of isolated fragments by dideoxy nucleotide methodology using an automated sequencer (Model 373; Applied Biosystems, Foster City, CA, USA). We analyzed nucleotide sequences of the PCR products using Align ${ }^{\mathrm{TM}}$ and Contig ${ }^{\mathrm{TM}}$ sequence-alignment software programs (Vector NTI ${ }^{\mathrm{TM}}$; Informax Inc., North Bethesda, MD, USA) and compared them with known sequences using the National Center for Biotechnology Information Basic Local Alignment Search Tool program [47], and with the IMGT/HLA database [48]. We designed primer pairs appropriate for real-time PCR based on the elucidated penguin sequences for each gene; we confirmed putative real-time primers on real-time PCR, purified the PCR product (Zymo DNA Clean and Concentrator-5 Kit), and sent the PCR product to sequencing for validation (Table 2).

\subsection{Real-Time Polymerase Chain Reaction}

We ran real-time PCR systems for the individual, gentoo, and rockhopper-specific reference genes and genes of interest in separate wells (Table 1). Briefly, we added $1 \mu \mathrm{L}$ of cDNA to a mix containing $12.5 \mu \mathrm{L}$ of QuantiTect Fast SYBR Green ${ }^{\circledR}$ Master Mix $\left(5 \mathrm{mM} \mathrm{Mg}^{2+}\right)$ (Qiagen, Hilden, Germany), $0.5 \mu \mathrm{L}$ each of forward and reverse sequence-specific primers, and $10.5 \mu \mathrm{L}$ of RNase-free water; total reaction mixture was $25 \mu \mathrm{L}$. We loaded the reactionmixture cDNA samples for each gene of interest and the reference genes into MicroAmp Fast Optical ${ }^{\circledR}$ 96-well reaction plates in duplicate and sealed them with optical sealing tape (Applied Biosystems, Bedford, MA, USA). We used reaction mixtures containing water but no cDNA as negative controls; thus, we ran approximately two individual penguin samples per plate. We conducted amplifications on a QuantStudio 3 Real-time Thermal Cycler (Applied Biosystems, Bedford, MA, USA) using QuantStudio 3 Software. Reaction 
conditions were as follows: an initial hold stage of $95^{\circ} \mathrm{C}$ for $20 \mathrm{~s}, 40$ cycles of $95^{\circ} \mathrm{C}$ for $1 \mathrm{~s}$, and $60{ }^{\circ} \mathrm{C}$ for $20 \mathrm{~s}$. The melt curve consisted of $95^{\circ} \mathrm{C}$ for $1 \mathrm{~s}, 60^{\circ} \mathrm{C}$ for $20 \mathrm{~s}, 0.3{ }^{\circ} \mathrm{C} / \mathrm{s}$ temperature increase, and then $95^{\circ} \mathrm{C}$ for $1 \mathrm{~s}$. We evaluated the stability of reference genes (EF1a and YWHAZ) and ranked them using the web-based analysis tool RefFinder (https:/ / www.heartcure.com.au/reffinder/ (accessed on 2 October 2020; [49]). We normalized cycle threshold crossing values (CT) for the genes of interest to the more stable of the reference genes, YWHAZ.

Table 2. Gentoo and Rockhopper penguin-specific quantitative real-time polymerase chain reaction primers.

\begin{tabular}{|c|c|c|c|c|c|}
\hline Gene & Primer Name & FP1 & Primer Name & RP1 rc & Expected Amplicon (bp) \\
\hline AHR & Sphen. AHR F1 & aggacgattaaagtttctccat & Sphen. AHR R1rc & gatagatggtggctgcagg & 111 \\
\hline IL-18 & Sphen. IL18 F1 & tgttgtgagaaagaatgtggaa & Sphen. IL-18 R2rc & acttaaatgctctggagctac & 133 \\
\hline GATA3 & Sphen. GATA3 F1 & ggtccatgacaaccttgaag & Sphen. GATA3 R2rc & tgcatcggtgtcggtgtag & 137 \\
\hline PRDX6 & Sphen. PRDX6 F1 & aggacatcaatgcatacaacg & Sphen. PRDX6 R1rc & ccatccttgtccegctcat & 126 \\
\hline GHR & Sphen. GHR F1 & gatccaccaccaacagcag & Sphen. GHR R1rc & tggaactattgttgagagcct & 122 \\
\hline VEGFA & Sphen. VEGFA F1 & gccttgctcagagaggaga & Sphen. VEGFA R1rc & cacatctgcaagtgcgctc & 127 \\
\hline $\mathrm{Nr} 3 \mathrm{c} 1$ & Sphen. Nr3c1 F1 & tgcatcgctctctcagcag & Sphen. Nr3c1 R1rc & aaggagctaacgtctcatcc & 118 \\
\hline IFIT5 & Sphen. IFIT5 F2 & ttgccaggagaagtcttgtta & Sphen. IFIT5 R2rc & cttgaaagctttttgcagctg & 120 \\
\hline THRa & Sphen. THRa F1 & ggcagccactggaagcag & Sphen. THRa R1rc & ctcgctgaacgectccag & 107 \\
\hline PRDX4 & Sphen. PRDX4 F1 & agcatggattaatactcctcg & Sphen. PRDX4 R1rc & cttggtcttccagatatacac & 115 \\
\hline YWHAZ & Sphen. YWHAZ F1 & aaggagatgcagccaacaca & Sphen. YWHAZ R1rc & agttcagcaattgcttcatcaa & 136 \\
\hline MHC & Sphen. MHC class II F & aacggcaccgagcgggtgaggt & Sphen. MHC class II R & cccgtagttgtgttggcag & 198 \\
\hline IL-6 & Sphen. IL-6 F1 & cacctcatcctccgagact & Sphen. IL-6 R1rc & tgtaacaaaggattgtgcctg & 121 \\
\hline TNFRSF6 & Sphen. TNFRSF6 F1 & aatgtcgggagagactggaa & Sphen. TNFRSF6 R1rc & gaagtgactgagccaactgt & 117 \\
\hline HSP70 & Sphen. HSP70 F1 & gagcacaagcagaaagagct & Sphen. HSP70 R1rc & ttaatctacttcttcgatggtc & 119 \\
\hline
\end{tabular}

\subsection{Statistical Methods}

Our general approach was to evaluate the associations among gene expression levels, species, and locations. We analyzed qPCR data using normalized $\mathrm{C}_{\mathrm{T}}$ values (housekeeping gene threshold crossing subtracted from the gene of interest threshold crossing); the lower the normalized value, the more transcripts are present. A change in normalized value of 2 is approximately equivalent to a 4 -fold change in the amount of the transcript.

\section{Results}

\subsection{General Description}

We used a box-and-whisker plot to visually describe gene expression profiles by location (Figure 2). Although most population responses were overlapping to some degree, clear differences exist among responses for each location. Most genes showed fairly small ranges in expression; however, for growth hormone receptor (GHR), the range was relatively large, indicating a wider range of stimuli and responses (Figure 2). We calculated means and standard deviations for all variables across all sites and species (Table 3; Table S1). We used mixed-effects statistical models to simultaneously estimate and account for multiple influences (sex, location, and species) on gene expression levels, which make them appropriate for the multiple uncontrolled factors that occurred as a result of opportunistic samples acquired for this study (Table 4). We calculated parameter estimates for all model effects using the lme4 package in R 2.8.1 [50]. We calculated expression differences between species within the islands and Detroit Zoo as well as between rookeries at the islands using MANOVA (NCSS ${ }^{\odot}$ Statistical Software 2007, Kaysville, UT, USA). Significance was determined at $p \leq 0.05$. Location and species had significant effects on the expression levels of most genes, while sex significantly influenced expression levels of $50 \%$ of the genes examined (Table 4). 


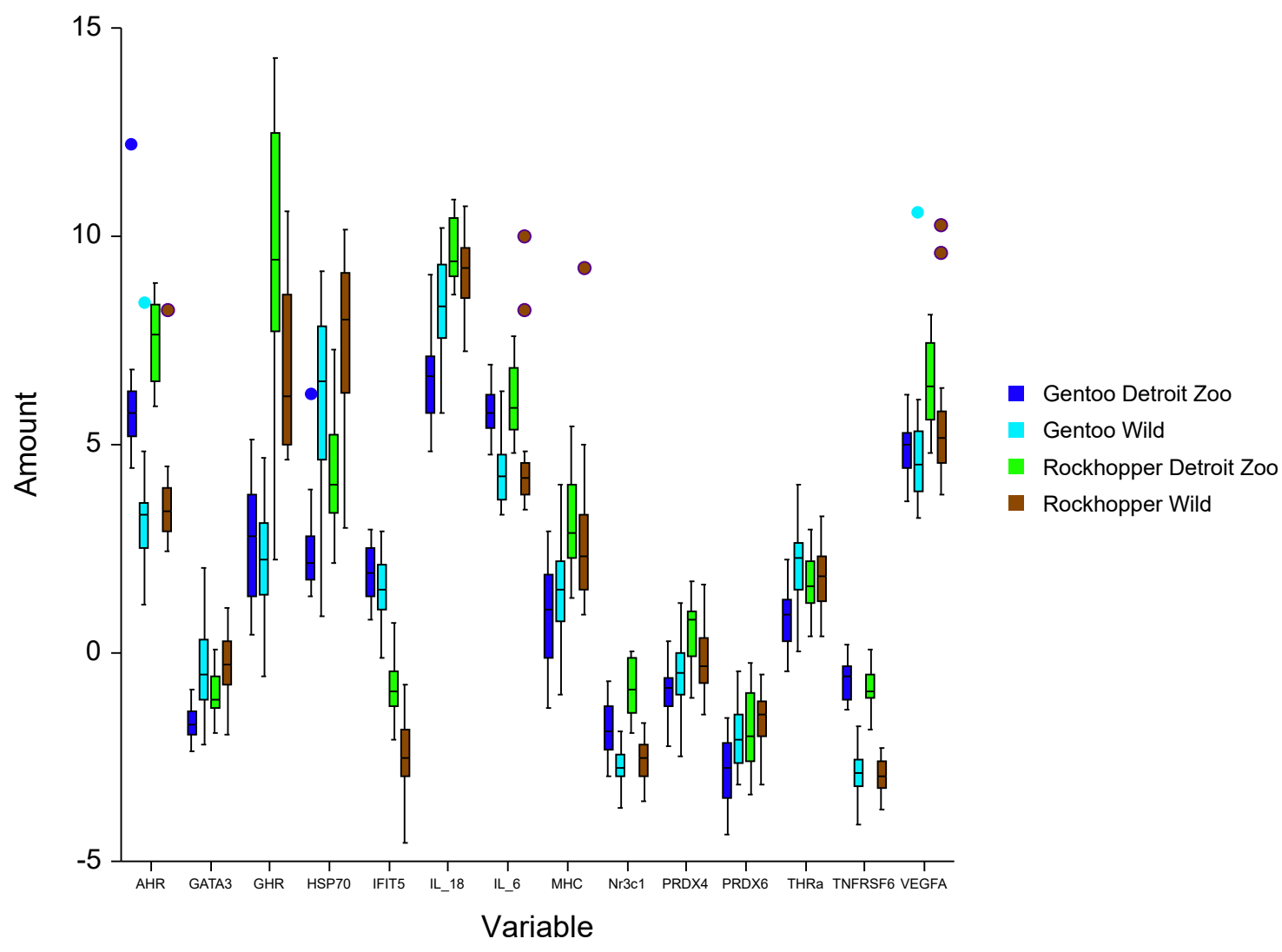

Figure 2. Distribution of average cycle threshold (CT) values across genes targeted by the panel of 14 primer pairs. Real-time PCR data are represented as normalized values (NVs); the lower the NV, the larger the quantity of transcripts. Blood was sampled from four groups of penguins during 2019 (gentoo Detroit Zoo, $n=23$; gentoo Falkland-Malvinas Islands (Wild), $n=39$; rockhopper Detroit Zoo, $n=15$; rockhopper Falkland-Malvinas Islands (Wild), $n=34$ ). Boxes are delineated by 25th and 75th percentiles. The 50th percentile median is indicated. Whisker length uses the classic method of box edge + (1.5; interquartile range), and severe outliers (circles) are calculated as box edge + (3; IQR). Interpretation of gene abbreviations is provided in Table 1.

We conducted two-dimensional non-parametric multidimensional scaling of the BrayCurtis dissimilarity from gene transcripts using the Vegan package in $\mathrm{R}$ version 3.5.0. We obtained vectors describing the strength of each gene contribution to the two non-metric multidimensional scaling (NMDS) axes for graphical display. We evaluated goodness of fit for NMDS models using stress plots. The graphical representations show individual penguins clustered by similarity in expression values and not by pre-defined groups such as location. Penguins are separated into four well-defined groups (NMDS; $2 D R^{2}=0.98$; Figure 3). Gene expression $\left(C_{T}\right)$ values differed among gentoo and rockhopper penguins sampled in the islands and at the Detroit Zoo (ANOSIM, $p<0.001$, global $\mathrm{R}=0.83$ ) and were confirmed by cluster analysis (SIMPROF, $p<0.001$ ). Vector analysis results show that the separation of Detroit Zoo and wild penguins is driven by higher levels of thyroid hormone receptor alpha (THRa), GATA3, peroxiredoxin 6 (PRDX6), and heat-shock protein 70 (HSP70) in Detroit Zoo penguins and higher levels of interleukin 6 (IL-6), tumor necrosis factor receptor super family 6 (TNFRSF6), aryl hydrocarbon receptor (AHR), and nuclear receptor subfamily 3 group $\mathrm{C}$ member $1(\mathrm{Nr} 3 \mathrm{c} 1)$ in wild penguins. The separation of rockhopper and gentoo penguins is driven by higher levels of interferon-induced protein with tetratricopeptide repeats 5 (IFIT5) in rockhopper penguins and higher levels of vascular endothelial growth factor A (VEGFA), peroxiredoxin 4 (PRDX4), GHR, IL-18, and major histocompatibility complex class II beta MHC in gentoo penguins. 
Table 3. Means and (standard deviations) for all variables across all sites and species. Note: higher numbers indicate less expression.

\begin{tabular}{|c|c|c|c|c|}
\hline & \multicolumn{2}{|c|}{ Gentoo } & \multicolumn{2}{|c|}{ Rockhopper } \\
\hline & $\begin{array}{l}\text { Falkland-Malvinas Islands } \\
\qquad n=39\end{array}$ & $\begin{array}{l}\text { Detroit Zoo } \\
\quad n=23\end{array}$ & $\begin{array}{l}\text { Falkland-Malvinas Islands } \\
\qquad n=34\end{array}$ & $\begin{array}{c}\text { Detroit Zoo } \\
n=15\end{array}$ \\
\hline AHR & $3.23(1.15)$ & $5.90(1.54)$ & $3.58(1.08)$ & $8.02(2.04)$ \\
\hline GATA3 & $-0.39(0.98)$ & $-1.73(0.44)$ & $-0.30(0.79)$ & $-0.96(0.52)$ \\
\hline GHR & $2.16(1.22)$ & $2.70(1.46)$ & $6.80(1.93)$ & $9.60(3.14)$ \\
\hline HSP70 & $6.07(2.19)$ & $2.40(1.04)$ & $7.49(0.83)$ & $4.43(1.58)$ \\
\hline IFIT5 & $1.50(0.85)$ & $1.86(0.83)$ & $-2.45(0.82)$ & $-0.79(0.74)$ \\
\hline IL-18 & $8.31(1.10)$ & $6.52(0.96)$ & $9.21(0.93)$ & $9.71(1.10)$ \\
\hline IL-6 & $4.40(0.84)$ & $5.78(0.58)$ & $4.44(1.27)$ & $6.02(0.74)$ \\
\hline MHC & $1.53(1.22)$ & $0.89(1.25)$ & $2.64(1.52)$ & $3.13(1.16)$ \\
\hline Nr3c1 & $-2.73(0.50)$ & $-1.83(0.64)$ & $-2.57(0.59)$ & $-0.84(0.68)$ \\
\hline PRDX4 & $-0.54(0.88)$ & $-0.91(0.69)$ & $-0.18(0.72)$ & $0.52(0.74)$ \\
\hline PRDX6 & $-2.00(0.74)$ & $-2.82(0.81)$ & $-1.58(0.62)$ & $-1.91(0.91)$ \\
\hline THRa & $2.03(0.93)$ & $0.87(0.74)$ & $1.82(0.76)$ & $1.67(0.71)$ \\
\hline TNFRSF6 & $-2.91(0.50)$ & $-0.62(0.48)$ & $-2.92(0.35)$ & $-0.81(0.46)$ \\
\hline VEGFA & $5.00(1.76)$ & $4.90(0.67)$ & $5.52(1.54)$ & $6.54(1.00)$ \\
\hline
\end{tabular}

Table 4. Mixed effects statistical models (corrected for multiple tests) were used to simultaneously estimate and account for multiple influences on gene expression levels. We used linear mixed-effects models to analyze the influence of sex, location, and species on each gene expression level. Parameter estimates for all model effects were calculated using the lme4 package in R 2.8.1 [50]. Significance was determined at $p \leq 0.05$. $p$ values are reported. Location and species had significant effects on the expression levels of most genes, while sex significantly influenced expression levels of $50 \%$ of the genes examined.

\begin{tabular}{lccc}
\hline \multicolumn{1}{c}{ Gene } & Sex & Location & Species \\
\hline AHR & $1.45 \times 10^{-5}$ & $<2.2 \times 10^{-16}$ & $5.9 \times 10^{-3}$ \\
\hline GATA3 & & $5.98 \times 10^{-10}$ & $1.0 \times 10^{-1}$ \\
\hline GHR & $8.6 \times 10^{-3}$ & $1.59 \times 10^{-5}$ & $<2.2 \times 10^{-16}$ \\
\hline HSP70 & $7.2 \times 10^{-3}$ & $4.01 \times 10^{-16}$ & $6.47 \times 10^{-7}$ \\
\hline IFIT5 & $4.34 \times 10^{-6}$ & $<2.2 \times 10^{-16}$ \\
\hline IL-18 & $7.7 \times 10^{-3}$ & $8.9 \times 10^{-4}$ & $6.97 \times 10^{-12}$ \\
\hline IL-6 & $3.11 \times 10^{-11}$ & \\
\hline MHC & $1.4 \times 10^{-3}$ & $<2.2 \times 10^{-16}$ & $2.875 \times 10^{-8}$ \\
\hline Nr3c1 & & & $1.17 \times 10^{-5}$ \\
\hline PRDX4 & & $6.0 \times 10^{-5}$ & $4.16 \times 10^{-5}$ \\
\hline PRDX6 & & $1.49 \times 10^{-5}$ & \\
\hline THRa & $3.7 \times 10^{-4}$ & $<2.2 \times 10^{-16}$ & $2.1 \times 10^{-2}$ \\
\hline TNFRSF6 & $4.0 \times 10^{-2}$ & & $1.6 \times 10^{-3}$ \\
\hline VEGFA & &
\end{tabular}




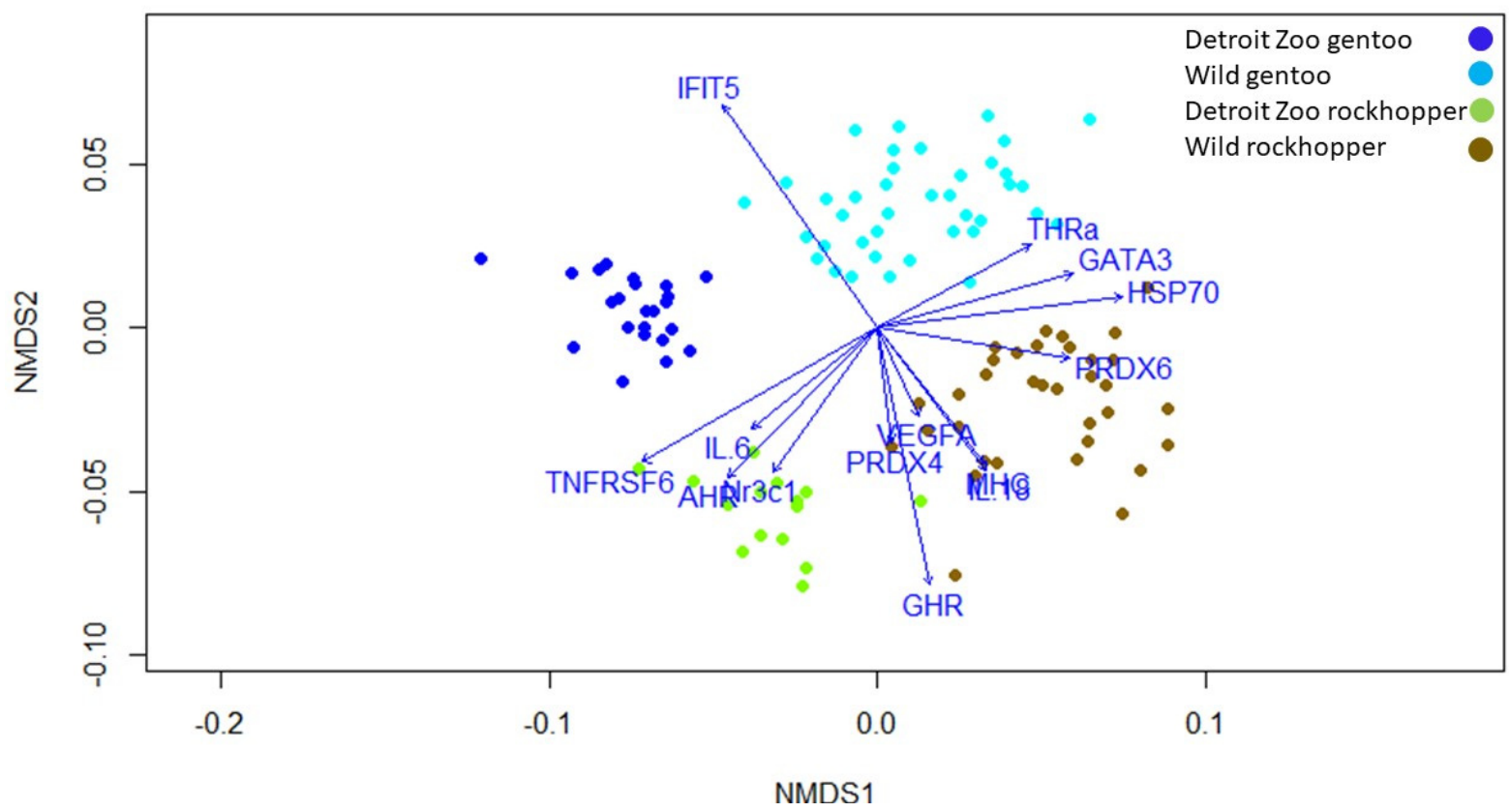

Figure 3. Two-dimensional non-parametric multidimensional scaling plot of the Bray-Curtis dissimilarity from gene transcript levels. The vector arrows signify the direction of maximum correlation for each gene in the ordination space and are significant at $p<0.05$. The length of the arrows signifies the strength of the relationship of each metric and the two NMDS metrics, with longer arrows signifying greater strength. There is clear clustering by site. Results show that the separation of Detroit Zoo and Falkland-Malvinas (Wild) penguins is driven by higher levels of THRa, GATA3, PRDX6, and HSP70 in Detroit Zoo penguins and higher levels of TNFRSF6, AHR, IL-6, and Nr3c1 in Falkland-Malvinas Island penguins. The separation of rockhopper and gentoo penguins is driven by higher levels of IFIT5 in rockhopper penguins and higher levels of GHR, IL-18, VEGFA, PRDX4, and MHC in gentoo penguins.

\subsection{Falkland-Malvinas Islands}

We found gene expression differences between species in the islands. Expression was higher in gentoo penguins for GHR, HSP70, IL-18, MHC, and PRDX6, and higher in rockhopper penguins for IFIT5 (Table 3). We also found gene expression differences between colonies within gentoo penguins. Gene expression levels for IFIT5, IL-18, and PRDX4 were all higher at Stanley in comparison with Dunbar colonies. We found minimal gene expression differences between colonies within rockhopper penguins. HSP70 expression was higher in rockhopper penguins sampled at Dunbar, while TNFRSF6 expression was higher in rockhopper penguins sampled at Stanley (data not shown).

\subsection{Detroit Zoo}

We found gene expression differences between species at the Detroit Zoo. Expression was higher in gentoo penguins for AHR, GATA3, GHR, HSP70, IL-18, MHC, Nr3c1, PRDX4, PRDX6, THRa, and VEGFA, and higher in rockhopper penguins for IFIT5 (Table 3).

\section{Discussion}

Although the shortcomings of these analyses are evidenced by the small sample sizes and brief timeframe in which the animals were sampled, the methodology we developed and applied to penguins in the Falkland-Malvinas Islands is a baseline to which future measurements can be compared, and thus subtle yet significant alterations in physiological status can be identified in real time, prior to catastrophic events. On a broad scale, these methods can serve as a template across species and landscapes, potentially serving as early-warning indicators ecosystem-level disruptions. As well, the stark differences in gene expression patterns between species and locations is intriguing and warrants further study. 
Implementation of long-term longitudinal sampling and transcriptomics would allow assessment of temporal increases or decreases of select expression and would facilitate interpretation of the drivers of change and health within populations.

In this study, we identified near complete statistical separation of penguin groups (gentoo Detroit Zoo, gentoo islands, rockhopper Detroit Zoo, and rockhopper islands) based on gene expression profiles. Individuals within a wild population comprise a range of physiological states. Variation in gene expression occurs in healthy individuals and can be attributed to both intrinsic and extrinsic factors [3]. However, without reference ranges for the genes in our panel specific to the species analyzed, comparisons among groups are relative. Although significantly different expression values may still fall within the range of "normal", differences are still indicative of differential intrinsic or extrinsic stimuli. One important difference between the sampled populations is age. Some captive penguins live into their 30s, and we can safely assume that the wild penguins are much younger. Additionally, penguins were sampled during breeding season in the Falkland-Malvinas Islands, while captive penguins were not sampled during breeding season. Although it is a logical conclusion that gene expression in some physiological systems may be altered by breeding status and/or age, the genes we have selected have not been examined in that light. While none of the genes in our panel is specific to ageing or reproduction, the complexities and interconnectedness of physiological systems in general require that we approach our results and interpretations with a degree of caution. Therefore, while we found expression differences between captive and wild penguins, we cannot, with certainty, attribute these differences to captive or wild environments; age and/or breeding status may contribute to expression differences.

\subsection{Gene Expression Differences by Sex}

Overall, females exhibited higher expression of AHR, IFIT5, interleukin 6 (IL-6), Nr3c1, TNFRSF6, and vascular endothelial growth factor A (VEGFA), while males exhibited higher expression of GHR. However, when analyzed separately by species and location, the effects of sex on gene expression were much lower. For example, sex had no influence on expression level among all genes in rockhopper penguins housed in the Detroit Zoo. Sex did influence expression levels of GHR and IL-18 (both higher in males) in gentoo penguins housed in the Detroit Zoo. As GHR expression was higher in male gentoo penguins in both locations, we would assume that GHR is reflective of a species-specific physiological adaptation. Females of both species sampled in the wild exhibited higher levels of genes indicative of stress (HSP70, rockhopper; $\mathrm{Nr} 3 \mathrm{c} 1$, gentoo). In captive gentoo penguins, males exhibited higher levels of IL-18, which is involved in inflammatory responses to tissue injury and/or microbial presence.

\subsection{Gene Expression Differences by Location}

We found expression differences between wild penguins and those at the Detroit Zoo, regardless of species. Expression of the AHR gene was higher in wild penguins than those at the Detroit Zoo. The AHR responds to classes of environmental toxicants, including polycyclic aromatic hydrocarbons, polyhalogenated hydrocarbons, dibenzofurans, and dioxin [28]. The islands are becoming increasingly important for oil exploration, and there may already be abundant hydrocarbon presence in the environment from anthropogenic sources (including in prey items) to stimulate a detoxification response in penguins. At the same time, wild penguins exhibited higher levels of response to virus (IFIT5, TNFRSF6), response to tissue damage (including inflammation and stress; IL-6), and stress associated with cortisol production ( $\mathrm{Nr} 3 \mathrm{c} 1)$. The combined effects of exposure to contaminants and pathogens may act synergistically to increase impacts to vulnerable populations. Penguins located at the Detroit Zoo, in comparison, expressed higher levels of HSP70. Additionally, penguins at the Detroit Zoo have evidence of higher responses to oxidative stress (PRDX6) and higher inflammatory responses (IL-18). 
Within wild gentoo (IFIT5, IL-18) and rockhopper (TNFRSF6) penguins we found increased response to virus at Stanley in comparison with Dunbar. Gentoo penguins also exhibited increased oxidative stress (PRDX4) at Stanley. Rockhopper penguins exhibited and increased general stress (HSP70) response at Dunbar. In addition to the differences in shipping/oil development between Dunbar (little) and Stanley (heavy), most of the island's human population live in Stanley. There are also approximately 2000 temporary inhabitants living on the Mount Pleasant military base to the south-west of Stanley. Without further investigation into rockhopper behavior patterns at Dunbar, it is difficult to explain the increased levels of stress response there.

\subsection{Gene Expression Differences by Species}

Although taxonomically similar at the family level, gentoo and southern rockhopper penguins maintain differences in biology and ecology and provide an interesting comparison on the potential effects of stressors and different routes for disease transmission. Gentoos are local foragers, while rockhoppers forage both locally and more distantly, which brings them into more potential contact with a variety of potential stressors, including hydrocarbons [14,51]. Gentoo and southern rockhopper penguins are genetically similar for the genes of interest in our study. Additionally, these two species inhabit the same habitat in the islands. Thus, the dramatic differences in gene expression between these two species in the wild would seem to be driven by differences in foraging strategies, prey items, and underlying physiological differences. While expression patterns in island gentoo penguins are indicative of relatively higher levels of nutrition, they also indicate increased levels of general stress and oxidative stress, accompanied by inflammation. Gentoo penguins also exhibit a higher response to bacterial pathogens. Rockhopper penguins in the islands exhibit a strong anti-viral response in comparison.

\section{Conclusions}

Population assessment and recovery planning focus on the inventory or number of animals; less attention is paid to identification of habitats, the effects of habitat fragmentation, and a more complete understanding of the quality or the health of individuals or populations. Wildlife health is determined by the cumulative effects of biological, environmental, and socioeconomic pressures acting on individuals and populations. As such, "health", when quantified, may be used to indicate resilience that reflects the capacity of wildlife to cope with and respond to natural and anthropogenic challenges. Improved knowledge of the health status of species considered vulnerable or at-risk may, therefore, provides valuable information for wildlife management, conservation assessments, and decision making. For example, Whitehead et al. [4] identified gene expression patterns in killifish (Fundulus grandis) that were predictive of exposure to hydrocarbon-like chemicals released in the Deepwater Horizon oil spill. Mancia et al. [5] identified gene expression signatures associated with capture stress in wild dolphins (Tursiops truncatus). Miller et al. [6] identified a mortality-specific gene expression signature in ocean-tagged sockeye salmon (Oncorhynchus nerka), enabling predictions of spawning success. Tinker et al. [7] included gene expression in an analysis of sea otter population collapse, offering substantive data supporting a controversial predation hypothesis. Broad-scale identification of gene expression patterns can provide mechanistic proxies of health [52]. Identifying causal links between exposure to stressors; gene transcript patterns; and individual, population, and ecosystem health is possible.

Supplementary Materials: The following supporting information can be downloaded at: https: / / www.mdpi.com/article/10.3390/life12020258/s1, Table S1: Normalized values of target genes for all samples included in this study. 


\begin{abstract}
Author Contributions: Conceptualization, L.B., S.W. (Shannon Waters) and R.M.; methodology, L.B., S.W. (Shannon Waters), R.M., A.D. and S.W. (Sarah Woodhouse); formal analysis, L.B.; original draft preparation, L.B., S.W. (Shannon Waters) and J.L.S.; review and editing, R.M., A.D. and S.W. (Shannon Waters); field sampling, A.D. and S.W. (Sarah Woodhouse). All authors have read and agreed to the published version of the manuscript.
\end{abstract}

Funding: This research was funded in part by U.S. Geological Survey and the Detroit Zoological Society.

Institutional Review Board Statement: The study was conducted according to the guidelines of the Declaration of Helsinki and approved by the Institutional Review Board (or Ethics Committee) of the Detroit Zoological Society.

Informed Consent Statement: Not applicable.

Data Availability Statement: The data presented in this study are available in Supplementary Material Table S1.

Acknowledgments: We would like to thank Josh Adams for his insightful review of this paper. Any use of trade, firm, or product names is for descriptive purposes only and does not imply endorsement by the US Government.

Conflicts of Interest: The authors declare no conflict of interest.

\title{
References
}

1. Faulkner, C.B.; Simecka, J.W.; Davidson, M.K.; Davis, J.K.; Schoeb, T.R.; Lindsey, J.R.; Everson, M.P. Gene expression and production of tumor necrosis factor alpha, interleukin 1, interleukin 6, and gamma interferon in C3H/HeN and C57BL/6N mice in acute Mycoplasma pulmonis disease. Infect. Immun. 1995, 63, 4084-4090. [CrossRef] [PubMed]

2. Acevedo-Whitehouse, K.; Duffus, A.L.J. Effects of Environmental Change on Wildlife Health. Philos. Trans. R. Soc. B 2009, 364, 3429-3438. [CrossRef] [PubMed]

3. McLoughlin, K.; Turteltaub, K.; Bankaitis-Davis, D.; Gerren, R.; Siconolfi, L.; Storm, K.; Cheronis, J.; Trollinger, D.; Macejak, D.; Tryon, V.; et al. Limited dynamic range of immune response gene expression observed in healthy blood donors using RT-PCR. Mol. Med. 2006, 12, 185-195. [CrossRef] [PubMed]

4. Whitehead, A.; Dubansky, B.; Bodinier, C.; Garcia, T.I.; Miles, S.; Pilley, C.; Raghunathan, V.; Roach, J.L.; Walker, N.; Walter, R.B.; et al. Genomic and physiological footprint of the Deepwater Horizon oil spill on resident marsh fishes. Proc. Natl. Acad. Sci. USA 2012, 109, 20298-20302. [CrossRef] [PubMed]

5. Mancia, A.; Warr, G.W.; Champman, R.W. A transcriptomic analysis of the stress induced by capture-release health assessment studies in wild dolphins (Tursiops truncatus). Mol. Ecol. 2008, 17, 2581-2589. [CrossRef]

6. Miller, K.M.; Li, S.; Kaukinen, K.H.; Ginther, N.; Hammill, E.; Curtis, J.M.R.; Patterson, D.A.; Sierocinski, T.; Donnison, L.; Pavlidis, P.; et al. Genomic signatures predict migration and spawning failure in wild Canadian salmon. Science 2011, 331, $214-217$. [CrossRef] [PubMed]

7. Tinker, M.T.; Bodkin, J.L.; Bowen, L.; Ballachey, B.; Bentall, G.; Burdin, A.; Coletti, H.; Esslinger, G.; Hatfield, B.B.; Kenner, M.C.; et al. Sea otter population collapse in southwest Alaska: Assessing ecological covariates, consequences, and causal factors. Ecol. Monogr. 2021, 91, e01472. [CrossRef]

8. Blanchong, J.A.; Robinson, S.J.; Samuel, M.D.; Foster, J.T. Application of Genetics and Genomics to Wildlife Epidemiology: Genetics and Wildlife Epidemiology. J. Wildl. Manag. 2016, 80, 593-608. [CrossRef]

9. Signa, G.; Mazzola, A.; Vizzini, S. Seabird influence on ecological processes in coastal marine ecosystems: An overlooked role? A critical review. Estuar. Coast Shelf Sci. 2021, 250, 107164. [CrossRef]

10. Sydeman, W.J.; Thompson, S.A.; Kitaysky, A. Seabirds and climate change: Roadmap for the future. Mar. Ecol. Prog. Ser. 2012, 454, 107-117. [CrossRef]

11. Provencher, J.F.; Ammendolia, J.; Rochman, C.M.; Mallory, M.L. Assessing plastic debris in aquatic food webs: What we know and don't know about uptake and trophic transfer. Environ. Rev. 2019, 27, 304-317. [CrossRef]

12. Croxall, J.P.; Butchart, S.H.; Lascelles, B.E.; Stattersfield, A.J.; Sullivan, B.E.; Symes, A.; Taylor, P.H. Seabird conservation status, threats and priority actions: A global assessment. Bird Conserv. Int. 2012, 22, 1-34. [CrossRef]

13. Trathan, P.N.; García-Borboroglu, P.; Boersma, D.; Bost, C.A.; Crawford, R.J.M.; Crossin, G.T.; Cuthbert, R.J.; Dann, P.; Davis, L.S.; De La Puente, S.; et al. Pollution, habitat loss, fishing, and climate change as critical threats to penguins. Conserv. Biol. 2015, 29, 31-41. [CrossRef] [PubMed]

14. Borboroglu, P.G.; Boersma, P.D. Penguins: Natural History and Conservation; University of Washington Press: Washington, DC, USA, 2015.

15. Burfield, I.J.; Butchart, S.H.; Collar, N.J. BirdLife, conservation and taxonomy. Bird Conserv. Int. 2017, 27, 1-5. [CrossRef] 
16. Bowen, L.; Miles, A.K.; Murray, M.; Haulena, M.; Tuttle, J.; Van Bonn, W.; Adams, L.; Bodkin, J.L.; Ballachey, B.; Estes, J.; et al. Gene transcription in sea otters (Enhydra lutris); development of a diagnostic tool for sea otter and ecosystem health. Mol. Ecol. Resour. 2012, 12, 67-74. [CrossRef]

17. Aarem, J.; Brunborg, G.; Aas, K.K.; Harbak, K.; Taipale, M.M.; Magnus, P.; Knudsen, G.P.; Duale, N. Comparison of blood RNA isolation methods from samples stabilized in Tempus tubes and stored at a large human biobank. BMC Res. 2016, 9, 430. [CrossRef]

18. Bowen, L.; Miles, A.K.; Kolden, C.A.; Saarinen, J.A.; Bodkin, J.L.; Murray, M.J.; Tinker, M.T. Effects of wildfire on sea otter (Enhydra lutris) gene transcription profiles. Mar. Mamm. Sci. 2015, 31, 191-210. [CrossRef]

19. Olias, P.; Adam, I.; Meyer, A.; Scharff, C.; Gruber, A.D. Reference genes for quantitative gene expression studies in multiple avian species. PLoS ONE 2014, 9, e99678. [CrossRef]

20. Miller, K.M.; Günther, O.P.; Li, S.; Kaukinen, K.H.; Ming, T.J. Molecular indices of viral disease development in wild migrating salmon. Conserv. Physiol. 2017, 5, cox036. [CrossRef]

21. Rohaim, M.A.; Santhakumar, D.; Naggar, R.F.E.; Iqbal, M.; Hussein, H.A.; Munir, M. Chickens Expressing IFIT5 Ameliorate Clinical Outcome and Pathology of Highly Pathogenic Avian Influenza and Velogenic Newcastle Disease Viruses. Front. Immunol. 2018, 9, 2025. [CrossRef]

22. Castell, J.V.; Gómez-Lechón, M.J.; David, M.; Andus, T.; Geiger, T.; Trullenque, R.; Fabra, R.; Heinrich, P.C. Interleukin-6 is the major regulator of acute phase protein synthesis in adult human hepatocytes. FEBS Lett. 1989, 242, 237-239. [CrossRef]

23. Gelain, M.E.; Bonsembiante, F. Acute Phase Proteins in Marine Mammals: State of Art, Perspectives and Challenges. Front. Immunol. 2019, 10, 1220. [CrossRef] [PubMed]

24. Sallaberry-Pincheira, N.; González-Acuña, D.; Padilla, P.; Dantas, G.P.M.; Luna-Jorquera, G.; Frere, E.; Valdés-Velásquez, A.; Vianna, J.A. Contrasting patterns of selection between MHC I and II across populations of Humboldt and Magellanic penguins. Ecol. Evol. 2016, 6, 7498-7510. [CrossRef] [PubMed]

25. Sheriff, M.J.; Dantzer, B.; Delehanty, B.; Palme, R.; Boonstra, R. Measuring stress in wildlife: Techniques for quantifying glucocorticoids. Oecologia 2011, 166, 869-887. [CrossRef]

26. Wiens, G.D.; Glenney, G.W. Origin and evolution of TNF and TNF receptor superfamilies. Dev. Comp. Immuunol. 2011, 35, 1324-1335. [CrossRef]

27. Seirafian, S.; Prod'homme, V.; Sugrue, D.; Davies, J.; Fielding, C.; Tomasec, P.; Wilkinson, G.W. Human cytomegalovirus suppresses Fas expression and function. J. Gen. Virol. 2014, 95, 933-939. [CrossRef]

28. Oesch-Bartlomowicz, B.; Oesch, F. Phosphorylation of cytochromes P450: First discovery of a posttranslational modification of a drug-metabolizing enzyme. Biochem. Biophys. Resour. Commun. 2005, 338, 446-449. [CrossRef]

29. Karchner, S.I.; Franks, D.G.; Kennedy, S.W.; Hahn, M.E. The molecular basis for differential dioxin sensitivity in birds: Role of the aryl hydrocarbon receptor. Proc. Natl. Acad. Sci. USA 2006, 103, 6252-6257. [CrossRef]

30. Raccurt, M.; Baudimont, F.; Tirard, J.; Rey, B.; Moureaux, E.; Géloën, A.; Duchamp, C. Growing in Antarctica, a challenge for white adipose tissue development in Adélie penguin chicks (Pygoscelis adeliae). Am. J. Physiol.-Regul. Integr. Comp. Physiol. 2008, 295, R1671-R1679. [CrossRef]

31. Iwama, G.K.; Mathilakath, M.V.; Forsyth, R.B.; Ackerman, P.A. Heat shock proteins and physiological stress in fish. Am. Zool. 1999, 39, 901-909. [CrossRef]

32. Tsan, M.F.; Gao, B. Cytokine function of heat shock proteins. Am. J. Physiol. Cell Physiol. 2004, 286, C739-C744. [CrossRef] [PubMed]

33. De Maio, A. Heat shock proteins: Facts, thoughts, and dreams. Shock 1999, 11, 1-12. [CrossRef] [PubMed]

34. Bourgeon, S.; Martínez, J.; Criscuolo, F.; Maho, Y.L.; Raclot, T. Fasting-induced changes of immunological and stress indicators in breeding female eiders. Gen. Comp. Endocr. 2006, 147, 336-342. [CrossRef] [PubMed]

35. Krumm, B.; Meng, X.; Li, Y.; Xiang, Y.; Deng, J. Structural basis for antagonism of human interleukin 18 by poxvirus interleukin 18-binding protein. Proc. Natl. Acad. Sci. USA 2008, 105, 20711-20715. [CrossRef] [PubMed]

36. Schneider, K.; Puehler, F.; Baeuerle, D.; Elvers, S.; Staeheli, P.; Kaspers, B.; Weining, K.C. cDNA Cloning of Biologically Active Chicken Interleukin-18. J. Interf. Cytok. Res. 2000, 20, 879-883. [CrossRef]

37. Parham, P. The Immune System, 4th ed.; Garland Science, Taylor and Francis Group, LLC: New York, NY, USA, 2014.

38. Capilla-Lasheras, P.; Dominoni, D.M.; Babayan, S.A.; O'Shaughnessy, P.J.; Mladenova, M.; Woodford, L.; Pollock, C.J.; Barr, T.; Baldini, F.; Helm, B. Elevated immune gene expression is associated with poor reproductive success of urban blue tits. Front. Ecol. Evol. 2017, 5, 64. [CrossRef]

39. Rey, B.; Degletagne, C.; Bodennec, J.; Monternier, P.A.; Mortz, M.; Roussel, D.; Romestaing, C.; Rouanet, J.L.; Tornos, J.; Duchamp, C. Hormetic response triggers multifaceted anti-oxidant strategies in immature king penguins (Aptenodytes patagonicus). Free Radic. Bio Med. 2016, 97, 577-587. [CrossRef] [PubMed]

40. Rey, B.; Dégletagne, C.; Duchamp, C. Transcriptomic data analysis and differential gene expression of antioxidant pathways in king penguin juveniles (Aptenodytes patagonicus) before and after acclimatization to marine life. Data Brief. 2016, 9, 549-555. [CrossRef]

41. Yamada, S.; Guo, X. Peroxiredoxin 4 (PRDX4): Its critical in vivo roles in animal models of metabolic syndrome ranging from atherosclerosis to nonalcoholic fatty liver disease. Pathol. Int. 2018, 68, 91-101. [CrossRef] 
42. Dégletagne, C.; Roussel, D.; Rouanet, J.L.; Baudimont, F.; Moureaux, E.M.; Harvey, S.; Duchamp, C.; Le Maho, Y.; Raccurt, M.; Laudet, V. Growth prior to thermogenesis for a quick fledging of Adélie penguin chicks (Pygoscelis adeliae). PLoS ONE 2013, 8, e74154. [CrossRef]

43. Dehkhoda, F.; Lee, C.M.M.; Medina, J.; Brooks, A.J. The growth hormone receptor: Mechanism of receptor activation, cell signaling, and physiological aspects. Front. Endocrinol. 2018, 9, 35. [CrossRef] [PubMed]

44. Deng, L.; Zhang, W.M.; Lin, H.R.; Cheng, C.H. Effects of food deprivation on expression of growth hormone receptor and proximate composition in liver of black seabream Acanthopagrus schlegeli. Comp. Biochem. Physiol. 2004, 137, 421-432. [CrossRef] [PubMed]

45. Yang, J.; Yan, J.; Liu, B. Targeting VEGF/VEGFR to modulate antitumor immunity. Front. Immunol. 2018, 9, 978. [CrossRef]

46. Bowen, L.; Riva, F.; Mohr, C.; Aldridge, B.; Schwartz, J.; Miles, A.K.; Stott, J.L. Differential gene expression induced by exposure of captive mink to fuel oil: A model for the sea otter. EcoHealth 2007, 4, 298-309. [CrossRef]

47. Altschul, S.F.; Gish, W.; Miller, W.; Myers, E.W.; Lipman, D.J. Basic local alignment search tool. J. Mol. Biol. 1990, 215, 403-410. [CrossRef]

48. Robinson, J.; Waller, M.; Parham, P.; Bodmer, J.G.; Marsh, S.G.E. IMGT/HLA Database—A sequence database for the human major histocompatibility complex. Nucl. Acids Res. 2001, 29, 210-213. [CrossRef] [PubMed]

49. Xie, F.; Xiao, P.; Chen, D.; Xu, L.; Zhang, B. miRDeepFinder: A miRNA analysis tool for deep sequencing of plant small RNAs. Plant Mol. Biol. 2012, 80, 75-84. [CrossRef]

50. R Development Core Team. R: A Language and Environment for Statistical Computing; R Foundation for Statistical Computing: Vienna, Austria, 2012; Available online: http:/ / www.R-project.org/ (accessed on 2 October 2020).

51. Boersma, P.D.; Stokes, D.L.; Strange, I.J. Applying ecology to conservation: Tracking breeding penguins at New Island South reserve, Falkland Island. Aquat. Conserv. 2002, 12, 63-74. [CrossRef]

52. Pedersen, A.B.; Babayan, S.A. Wild immunology. Mol. Ecol. 2011, 20, 872-880. [CrossRef] 